\title{
LEGAL TECH IN LEGAL SERVICE: CHALLENGING THE TRADITIONAL LEGAL LANDSCAPE IN MALAYSIA
}

\author{
Juriah Abd Jalil* \\ Shukriah Mohd Sheriff***
}

\begin{abstract}
Digital technologies are now extending its function to the legal profession. But the existence of these technologies otherwise known as legal technology (legal tech) or law tech is challenging the traditional legal profession. The nature of legal practice regulation in Malaysia and the United Kingdom (UK) permits only lawyers and authorised persons as legal service providers. As a result, the legal tech or law tech companies although able to facilitate the service in the legal profession are met with resistance and/or indifference. Should the traditional legal profession fear the invasion of this legal tech? This article aims to analyse the situation in Malaysia and the UK. It examines the impact of technology on legal service and legal profession in Malaysia and in the UK. The article also highlights the implication of this legal technology on the laws governing the legal profession in Malaysia. Through analyses of key Malaysian cases, the study finds that the Bar Council has the power to halt the operation of legal tech companies in providing any legal service in this country.As a result, the Bar has been criticised for being a hindrance to the development of legal tech in Malaysia. In contrast, the UK and the United States of America (US) have been very receptive to legal technology despite the exclusivity in the legal profession.
\end{abstract}

Keywords: legal technology, legal service, legal profession, digital technologies.

Associate Professor at the Department of Legal Practice, Ahmad Ibrahim Kulliyyah of Laws, International Islamic University of Malaysia. Email: juriah@iium.edu.my.

** Assistant Professor at the Department of Legal Practice, Ahmad Ibrahim Kulliyyah of Laws, International Islamic University of Malaysia. Email: shukriahs@iium.edu.my. 


\title{
TEKNOLOGI UNDANG-UNDANG DALAM PERKHIDMATAN UNDANG-UNDANG: CABARAN TERHADAP LANDSKAP PERUNDANGAN TRADISIONAL DI MALAYSIA
}

\begin{abstract}
ABSTRAK
Teknologi digital kini sedang memperluaskan fungsinya kepada profesion undang-undang. Akan tetapi khidmat teknologi digital perundangan yang diperkenalkan oleh syarikat-syarikat teknologi telah mencabar profesion undang-undang tradisional. Perkhidmatan perundangan di Malaysia dan di United Kingdom hanya boleh ditawarkan secara eksklusif oleh peguam dan individu yang diberi kuasa sahaja. Ini mengecualikan perkhidmatan undangundang yang ditawarkan oleh syarikat-syarikat teknologi digital tersebut. Oleh itu, teknologi digital, walaupun mampu memperkasakan cara pengendalian dan penyampaian perkhidmatan undang-undang, ianya hanyalah dipandang sepi dan tidak diterima oleh profesion undang-undang. Adakah profesion undang-undang yang bersifat tradisional ini merasa tercabar dan takut dengan kewujudan teknologi ini? Artikel ini bertujuan untuk mengkaji dan menganalisa keadaan dan penerimaan teknologi undangundang di Malaysia dengan penerimaan teknologi undang-undang di United Kingdom (UK). Ia mengkaji kesan teknologi perkhidmatan undang-undang dan profesion undang-undang di Malaysia dan di UK. Artikel ini juga menyoroti implikasi teknologi undang-undang ini ke atas undang-undang yang mengawal selia profesion undang-undang di Malaysia. Melalui analisis kes-kes berkenaan teknologi undang-undang di Malaysia, kajian mendapati Majlis Peguam mempunyai kuasa untuk menghentikan operasi syarikat teknologi ini dalam menyediakan perkhidmatan undang-undang di Malaysia. Akibatnya, Majlis Peguam telah dikritik kerana menjadi penghalang kepada pembangunan teknologi undang-undang di Malaysia. Sebaliknya, UK dan Amerika Syarikat (USA) sangat terbuka dalam menerima teknologi undangundang walaupun profesion undang-undang mereka adalah bersifat eksklusif.
\end{abstract}

Kata kunci: teknologi undang-undang, perkhidmatan undang-undang, profesion undang-undang, teknologi digital. 


\section{INTRODUCTION}

In many parts of the world, the legal profession appears to be threatened by the existence of legal tech companies in the legal service industry. ${ }^{1}$ Traditionally, the exclusivity of the legal profession is protected by an exclusive domain of lawyers. The underlying principle behind this tradition is trust, confidentiality, duties, and responsibilities that lawyers owe to their clients, the courts, the public, and the profession. Accordingly, lawyers find it hard to open the profession to others.

However, digital technologies are challenging this tradition by allowing any non-lawyers to provide legal services online. ${ }^{2}$ This is evidenced by the mushrooming of legal tech companies in many parts of the world including Malaysia. The service offered connects clients with online-based lawyers or software tools capable of circumventing the need for traditional lawyers in some contractual transactions. Accordingly, the existence of this legal tech and start-ups creates a fear that lawyers may lose their job or may have to compete with nonlawyers and artificial lawyers. ${ }^{3}$ This may also challenge the power of the Bar as the guardian of the legal profession. This article aims to analyse and examine the impact of technology on legal service and the legal profession in Malaysia and the United Kingdom (UK). It also highlights the implication of the laws governing the legal profession in Malaysia.

1 Kenneth Tung, "If "Software is Eating the World," Is Legal Service is on the Menu?" Legal Business World 10, 2017, https://www.legalbusinessworld.com/single-post/2017/10/31/If$\% \mathrm{E} 2 \% 80 \% 9$ CSoftware-Is-Eating-the-World\%E2\%80\%9D-Is-LegalService-on-the-Menu.

2 Qian Hongdao, Sughra Bibi, Asif Khan, Lorenzo Ardito, and Mohammad Nurunnabi, "Legal Technologies in Action: The Future of the Legal Market in Light of Disruptive Innovation," Sustainability 11, 2019: 1015, https://doi:10.3390/sul1041015.

3 See "Lawtech Adoption Research Report 2019" The Law Society, accessed November 2, 2019, https://www.lawsociety.org.uk/supportservices/research-trends/law-society-lawtech-adoption-report-2019.pdf. 


\section{TECHNOLOGY, THE COURT, AND VIRTUAL LAWYERS}

When technology was initially introduced, it was met with resistance due to the concerns over invasion of privacy and security. The fear appears genuine because of security issues and data breaches which are still persistent. Other reasons include the fact that using technology requires understanding, knowledge, and costs. In fact, embracing technology involves a new learning process and a change of mindset within the legal service which is now becoming a competitive business. The change of this mindset may take a long time to achieve but eventually, lawyers and the legal profession must accept such changes or otherwise would face the risk of being left behind in the competition. But now, despite the unsettled privacy and security issues, people have become more dependent on technology. These among others explain why the legal tech is moving slowly in Malaysia.

Furthermore, technologies are developing too fast for the law and lawyers to catch up. Fahri Azzat, a practicing lawyer explains "the legal profession itself is conservative by nature" and that "the law has to be stable and predictable... Innovation, from the law perspective, is irregular and unpredictable". ${ }^{4}$ In addition, factors such as low technology awareness and knowledge among lawyers and high cost also contribute to this delay. This, therefore, explains why many law firms do not have their own websites, some prefer to keep physical documents rather than using online files such as cloud and some leave it to the more junior lawyers to handle technology matters without any interest to learn and use the technology. Another hindrance is that legal tech may be costly especially for small legal firms.

However, the courts are quite advanced in using technology tools including video conferencing, virtual court, and the use of hologram, e-filing or paperless court, and data sentencing as part of digitalisation of the judicial process. ${ }^{5}$ Thus, despite working in its

4 Kuek Ser Kwang Zhe, "New Horizon: Innovation and the Legal Profession," The Edge Malaysia, July 14, 2018, https://www.theedgemarkets.com/article/new-horizons-innovation-andlegal-profession.

5 See Speech of Chief Justice of Malaysia Tan Sri Datuk Seri Panglima Richard Malanjum at the Opening of Legal Year (OLY) 2019 at The 
exclusivity, lawyers have no choice but to adapt to technologies. Therefore, to match up the technology in court, lawyers too should embrace technology. This may be relatively easy for young lawyers who are digital natives and tech-savvy. They may use technology to improve legal research skills, update legal knowledge, and prepare court documents professionally. However, senior practitioners who see technology as burdensome may have difficulty to understand and apply digital legal skills. Nevertheless, the legal profession and lawyers must adopt technology and adapt to the digital environment so that "the legal profession can continue to play an important role in the delivery of legal service to the public". ${ }^{6}$ In fact, lawyers should take advantage of the existence of legal technology to expand legal service inclusion.

The existence of ROSS, the first virtual lawyer powered by artificial intelligence and has proven to supersede human intelligence. ROSS assists lawyers in finding case law, relevant legislation, and thousands of legal documents. It also interacts with lawyers in plain English. ${ }^{7}$ Its intelligence resides in the engine of IBM Watson. Although ROSS does not appear in any court, he advises other lawyers in the firm of BakerHostetler, one of the largest law firms in the United States of America (US). ${ }^{8}$ However, ROSS's existence

Putrajaya Marriott Hotel, Putrajaya, January 11, 2019, https://www.kehakiman.gov.my/sites/default/files/OLY\%202019\%20CJ $\% 27$ s\%20Speech\%20-0\%20Final_0.pdf.

6 "Deep Thinking: The Future of the Legal Profession in an Age of Technology," Speech of Chief Justice of Singapore Sundraresh Menon at the $29^{\text {th }}$ Inter-Pacific Bar Association Annual Meeting and Conference in Singapore, April 2019, https://www.supremecourt.gov.sg/docs/default-source/defaultdocument-library/deep-thinking---the-future-of-the-legal-profession-inan-age-of-technology-(250419---final).pdf.

7 Karen Turner, "Meet 'ROSS' the Newly Hired Legal Robot,"The Washington Post, May 16, 2016, https://www.washingtonpost.com/news/innovations/wp/2016/05/16/mee t-ross-the-newly-hired-legal-robot/.

8 Cecille De Jesus, "AI Lawyer "Ross" Has Been Hired By Its First Official Law Firm,"May 11, 2019, Futurism.com, accessed on November 5, 2019, https://futurism.com/artificially-intelligent-lawyer-ross-hired-firstofficial-law-firm. 
triggered the important question-, will it replace lawyers? Should lawyers be worried that robots will replace them?

Addressing this issue, Bob Craig, the chief information officer of BakerHostetler said that ROSS is a supplemental tool to help lawyers move faster, learn faster, and continually improve. ${ }^{9}$ In fact, with ROSS's assistance, lawyers have more time to focus on their clients and be more creative in preparing legal arguments, and cases. Thus, ROSS helps by saving time spent in researching pages of cases, legal documents and relevant passages of the law. ROSS also monitors the law round the clock, as well as new court decisions that can affect the case. ${ }^{10}$

In addition, ROSS also possesses the ability to interact with lawyers. According to Andrew Arruda, the chief executive of ROSS Intelligence, "ROSS surfaces relevant passages of law and then allows lawyers to interact with them. Lawyers can either enforce ROSS's hypothesis or get it to question its hypothesis". ${ }^{11}$ Therefore, ROSS is just a tool to help with knowledge management, particularly, in keeping up with the latest legislation. Its existence is, therefore, not to replace lawyers. ${ }^{12}$ Furthermore, ROSS is accessed via a computer and is billed as a subscription service. ROSS can be considered as the pioneer of legal tech start-ups. Will the service provided by ROSS and the legal start-ups be allowed by the Malaysian Bar?

9 Karen Turner, "Meet 'ROSS' the Newly Hired Legal Robot,"The Washington Post, May 16, 2016, https://www.washingtonpost.com/news/innovations/wp/2016/05/16/mee t-ross-the-newly-hired-legal-robot/.

10 Cecille De Jesus, "AI Lawyer "Ross" Has Been Hired By Its First Official Law Firm," May 11, 2019, Futurism.com, accessed on November 5, 2019, https://futurism.com/artificially-intelligent-lawyer-ross-hired-firstofficial-law-firm.

11 Karen Turner, "Meet 'ROSS' the Newly Hired Legal Robot,"The Washington Post, May 16, 2016, https://www.washingtonpost.com/news/innovations/wp/2016/05/16/mee t-ross-the-newly-hired-legal-robot/.

12 IBM Cognitive Business, "How Watson Helps Lawyers Find Answers in Legal Research. Ross Intelligence Takes Watson to Law School," Medium.com, accessed on November 5, 2019, https://medium.com/cognitivebusiness/how-watson-help-Lawyers-findanswers-in-lega-research-672ea028dfb8. 


\section{THE LEGAL PROFESSION AND THE BAR IN MALAYSIA}

The legal profession in Malaysia belongs exclusively to lawyers who have been admitted to the Malaysian Bar and practice at the High Court of Malaya and the High Court of Sabah and Sarawak. The profession is governed by the Legal Profession Act 1976 (LPA) and the Malaysian Bar is a professional body that regulates the profession of lawyers in this country. The purpose of the Malaysian Bar is inter alia to uphold justice; maintain and improve the standard of conduct and learning of the legal profession, represent, protect and assist members or of the legal profession; promote in any proper manner the interest of the legal profession, and protect and assist the public in all matters touching ancillary or incidental to the law. ${ }^{13}$ The Bar also has the power and locus standi under Section 41 (2) of the LPA to commence an action in court and to apply for an injunction in order to protect the profession. In the meantime, advocates and solicitors in Malaysia are members of the Bar and they are the only authorised persons to represent a client in court, to conduct and offer any legal service. Section 37 of the $\mathrm{LPA}^{14}$ prevents a non-authorised person from representing a client in court or to conduct any legal service. A breach of this provision amounts to an offence. This provision clearly shows that non-lawyers are "not welcomed" to the profession. At the same time, lawyers are prohibited from touting or soliciting clients under the Legal Profession (Practice and Etiquette) Rules 1978 (LPPER). Thus, any service relating to this matter will be considered a breach of this provision. Therefore, the current LPA presents a stumbling block to the development of legal tech in Malaysia.

\section{The Malaysian Bar and Legal Tech}

As mentioned above, Sections 41 and 42 of the LPA confer wide powers to the Bar to commence a suit against non-lawyers who purportedly breached the provision of the LPA. In 2012, the Bar brought an action against Index Continent Sdn. Bhd. to restrain the company from promoting its prepaid legal services on a subscription basis known as "answers-in-law". The service

\footnotetext{
13 Section 42 of the LPA 1976.

14 Section 37 deals with no unauthorised person to act as an advocate and solicitor.
} 
allows members of the public who are seeking legal assistance to contact lawyers who could answer their specific queries or assistance. The company clearly indicated in their advertisement through email and the internet that they are not providing any legal service. However, the Bar saw this as a breach of Sections $36^{15}$ and 37 of the LPA, and applied for an interim injunction to:

\begin{abstract}
"restrain the company from continuing to advertise, promote or otherwise communicate howsoever the prepaid legal service, from carrying and engaging in the provision of the service to members of the public and from directly or indirectly soliciting clients, members or subscribers for its answers-in-law scheme". ${ }^{16}$
\end{abstract}

The interim injunction was granted. However, the company continued to carry out the service. Hence, the Bar applied for an interlocutory injunction to:

"restrain the company from advertising, representing, and/or continuing to provide the prepaid legal services to the general public and from communicating with members of the legal profession about the service".

In opposing the application, the company argued as follows. Firstly, the plaintiff lacks substantive locus standi to bring the case. Secondly, Section 37 of the LPA is a penal provision which empowers the Attorney General's Office to commence action instead of the Bar Council. However, the arguments were rejected by the court on the ground of Sections 41 and 42 of the LPA. The court also rejected the company's argument that the Bar Council is a creature of LPA as such they must act and conduct their activities within the four corners of the statute.

15 Section 36 requires the advocate and solicitor to have a name on the Role before practice. The provision states "... no person shall practice as an advocate and solicitor unless his name is on the Roll and he has a valid practising certificate authorising him to do the act".

16 Bar Malaysia v Index Continent Sdn Bhd [2012] 4 MLJ 90 (HC). 
In relation to the service provided, the Bar Council contended that the business and the service provided by the company are "as though they are providing the service of advocates and solicitors" in breach of Section 36 of the LPA. The Bar Council also argued that the "services carried out and advertised are normally and customarily carried out or undertaken by an advocate and solicitor". On this issue, the company counter-argued that their emails and correspondences clearly indicated that the company is not providing legal services or holding itself as an advocate and solicitor. However, upon perusing the company emails and the contents of its website, the court opined that the packages being offered by the company is multilayered, in that, potential members could, inter alia:

i. Call in for an immediate phone consultation;

ii. Engage in web chat, presumably with an advocate and solicitor; or

iii. Have a face to face consultation with an advocate and solicitor.

Accordingly, the court regarded the issue of "whether the package falls within Section 37(3) of the LPA" as a question to be tried, and thus, allowed the application for an injunction. ${ }^{17}$ On the nature of legal service provided, the court held them as "matters touching ancillary or incidental to the law". Therefore, it is a breach of Section 37 of the LPA. Furthermore, if the service is allowed, it will cause greater harm to the public, and the Bar has a duty to protect the public, and that allowing the company to advertise may lead to dire consequences for which damages would not be an adequate remedy.

Apart from the above actions, the Bar has applied for an injunction against Euro Prestasi \& Partners (M) Sdn Bhd, a debt collection agency for representing itself as a law firm. Several other services provided by start-ups such as DragonLaw, BurgieLaw, CanLaw, and NeedLawyer were said to be in breach of the LPA

17 The company's appeal to the Court of Appeal was allowed. However, the Bar later appealed to the Federal Court. The Federal Court affirmed the decision of the High Court. Bar Malaysia v Index Continent Sdn Bhd [2016] 2 CLJ 545 (FC). 
and/or LPPER. ${ }^{18}$ Due to this strong stance by the Bar Council, many potential legal start-ups are prevented from providing such services. On this, Van Geyel, a partner in a law firm commented that "if the industry regulators are not playing their role of encouraging development and improvement, then at the very least they should not actively create barriers to innovations." 19

Prior to the above actions, the Bar Council had already sued a company for providing legal services. In 2003, the Malaysian Bar took an action against HF Vitality (Malaysia) Sdn. Bhd. ${ }^{20}$ for advertising and offering legal services to the general public under a scheme known as "The Rights Programme" where fees are charged to its members. In this case, the Bar Council contended that the program and the service provided intruded into the legal profession. The Bar Council also sought a declaration to announce that the company was not an authorised person to provide such services under the LPA.

The above cases illustrated the protective nature of the Malaysian Bar in guarding the legal profession and its members from unauthorised persons who are non-lawyers to provide legal service. The law applies to any type of legal services whether online or offline, thus, closing all doors to non-lawyers. The reason for such "cautious treatment" of the Bar Council is explained by the former President of the Bar Council, George Varughese, which is to:

"protect the legal profession from unscrupulous vendors and/or access to products and services that flout the LPA and related legislation or violate the rules and ruling of the Bar Council. It is also due to the need to ensure that access to legal services is properly regulated so

18 See Annual Reports 2017/2018 and 2016/2017 at https://www.malaysianbar.org.my. See also Fatimah Zahrah, "Malaysia Embracing Technology in the Legal Industry -"Adapt" or "be Drooped," accessed on 20 October, 2019, https://www.conventus law.com/report/Malaysia-embracing-technology-in-the-legal/.

19 Qian Hongdao, Sughra Bibi, Asif Khan, Lorenzo Ardito, and Mohammad Nurunnabi, "Legal Technologies in Action: The Future of the Legal Market in Light of Disruptive Innovation," Sustainability 11, 2019: 1015, https://doi:10.3390/sul1041015.

20 Bar Malaysia v HF Vitality (Malaysia) Sdn Bhd [2003] 5 MLJ 145. 
that the general public is protected in terms of their access, including with reference to the quality of legal services" 21

However, such a measure may have an adverse effect on the development of legal technology in Malaysia in contrast to the UK and the US.

\section{LEGAL TECHNOLOGY AND DIGITAL LEGAL SERVICE: THE US AND THE UK APPROACH}

Legal technology or legal tech involves the use of technology and software to provide legal services. Specifically, "it refers to the application of technology and software to help law firms with practice management, knowledge management, and document storage". ${ }^{22}$ Such services are provided by legal start-ups or IT companies that offer the above services to legal firms. In the US, for example, legal start-ups such as Wise Legal Services, Rocket Lawyer, Legal Zoom, and Legal Shield offer business models based on legal technologies to provide individuals and SMEs - Small and Medium Enterprises with online legal services including incorporation, estate plans, legal health diagnostics, billing, accounting, and e-discovery, on top of legal documentation automation, practice management, and document storage.

In 2016, the American Bar Association (ABA) produced a report on the "Future Legal Service in the United States". The Report found that legal tech could be used to expand the public's access to legal services which remain out of reach for the less privileged members of the society. The study conducted found that the traditional delivery of legal services and law practice business model

21 See Fatimah Zahrah, "Malaysia -Embracing Technology in the Legal Industry - "Adapt" or "be Drooped," accessed on 20 October, 2019, https://www.conventuslaw.com/report/Malaysia-embracing-technologyin-the-legal/.

22 Kenneth Tung, "If "Software is Eating the World," Is Legal Service is on the Menu?" Legal Business World 10, 2017, https://www.legalbusinessworld.com/single-post/2017/10/31/If$\%$ E2\%80\%9CSoftware-Is-Eating-the-World\%E2\%80\%9D-Is-LegalService-on-the-Menu. 
put constraints on innovation that would have provided greater access to and enhanced the delivery of legal services. The Report regarded the legal profession's resistance to change as a hindrance to additional innovations. On this point William C. Hubbard, the ABA President in 2014-15 said:

\begin{abstract}
"We must open our minds to innovative approaches and to leveraging technology in order to identify new models to deliver legal services. Those who seek legal assistance expect us to deliver legal services differently. It is our duty to the public and it is our duty to deliver justice, not just to some but to all". 23
\end{abstract}

In relation to the issue of unemployment of new graduates, the Report highlights that the legal start-ups could provide employment to recent law graduates to meet the need for legal services. The Report has provided twelve recommendations, one of which suggested that the legal profession should partner with other disciplines and the public for insights about innovative legal services delivery. This can be achieved by increasing collaboration with other disciplines which can help to improve access to legal services. In addition, the law schools and Bar Associations, including the ABA, should offer more continuing legal education and other opportunities for lawyers to study entrepreneurship, innovation, the business and economics of law practice, and other relevant disciplines. Accordingly, legal tech in the US is seen as a means to improve the delivery of legal services so that the public can be better served, thus justifying the cause of justice and the rule of law.

In the UK, the legal start-ups have made their presence in the so-called "outdated, inaccessible and expensive" legal profession. This was made possible through the use of automation, data, artificial intelligence, and other technologies to make the legal process faster, more efficient, and open to players with affordable costs. The most notable legal start-ups in the UK are Seedlegal, LegaleXe, JustBeagle, Lex Snap, Luminance, Libryo, and Lexoo. Thus, despite the conservative legal profession in

23 "Report on the Future of Legal Services in the United States," Commission on the Future of Legal Services, American Bar Association: Chicago, IL, USA, 2016. 
the UK, the Law Society of England and Wales Report 2017 on "Capturing Technological Innovation in Legal Services" clearly endorsed the need to embrace technology in the legal profession. According to Robert Bourns, the President of the Law Society, "the essential role of a solicitor to assist the client to the best of our abilities and uphold the rule of law, has not changed, but the way we do the jobs has evolved as the world we live and work in has."

The Law Society acknowledged that "change is important in order to provide value to clients but preserve essential elements of professional behaviour". With such reception, the Law Society aims "to change the legal profession to a profession that has energy and ideas that are ready to promote a revolution in the delivery of legal service". This may establish the connotation of "Lawyers on Demand'.

Similar to the approach made by the US, the UK also regards the development of this new and disruptive technology as a mechanism or opportunity to increase transparency and value of service across the sector. In order to see the reaction and reception of the members of the Law Society on this legal tech issue, the Law Society conducted a survey in February 2016. Even though $47 \%$ and $24 \%$ agreed and strongly agreed respectively that "innovation is critical to exploit opportunities and differentiate my firm", there is still a gap between those who recognised the need to change, and the need to take steps towards innovation. Furthermore, it is quite difficult to change from fee-earning partnerships to commercial business. Nevertheless, the pressure to adopt legal tech is building up due to various reasons including the need for greater efficiency, volume, and complexity of work. Above all is the increasing client demand on cost and speed which influences the pressure to adopt the legal tech.

In summary, lawyers in the US and the UK are more receptive and willing to invest in technology. They are inclined to adopt innovation to carry out the routine legal works as compared to the Malaysian lawyers. 


\section{DEVELOPMENT OF LEGAL TECH IN THE UK}

The legal profession in England has traditionally been highly monopolistic. The profession had always been pulling up the drawbridge; it regulated everyone else out of the field and kept the exclusive rights in place. The profession provides more to the interests of the lawyers or providers than the recipients of legal services i.e. the clients. Although the legal profession is old and traditional, it is not immune to changes. As seen earlier, the legal landscape in the UK especially England and Wales have gradually changed with the advent of technologies.

As a game-changer to the conservative profession, technologies also changed consumer preference from the good old lawyers and law firms towards solutions powered by technology. This is one of the driving factors for the birth of legal technology or legal tech in the UK and other parts of the world.

\section{The Law Society and the Legal Tech in the UK}

The Law Society in the UK is an independent body for solicitors. It aims to promote the role of legal services in the UK economy as well as protecting everyone's rights to have access to justice. The Law Society acknowledges the impact of technologies on legal practice and the justice system. It adopts the approach of using legal tech as an opportunity to innovate and provide better services for clients. Thus, legal tech becomes a mechanism to increase efficiency, reduce costs and improve outcomes. ${ }^{24}$

The Law Society defines legal tech as "technologies which aim to support, supplement or replace traditional methods for delivering legal services, or that improve the way the justice system operates". ${ }^{25}$ Thus, the aim of having legal tech is to facilitate, support, and improve the delivery of legal services that bring people closer to justice. In order to achieve this, the Law Society conducts legal tech programs to educate, assist, and facilitate its members. A committee

\footnotetext{
24 The Law Society, accessed on November 2, 2019, https://www.lawsociety.org.uk/support-services/lawtech/

25 "What is lawtech?" The Law Society, accessed on November 2, 2019,https://www.lawsociety.org.uk/support-services/lawtech/what-islawtech/.
} 
on Technology and Law has been established with intentions to provide advice and develop guidance that will assist the profession in adopting relevant new technologies and comply with IT-related professional obligations and regulatory requirements (including data protection and cybersecurity). In this manner, the Law Society can assist in shaping and developing policy initiatives including court modernisation. By doing so, the Law Society become an influential voice in the legal, regulatory, and ethical debates concerning the role of emerging new technologies including AI and machine learning, and their impact on the law and legal practice. Moreover, the Solicitors Regulation Authority (SRA) revealed a plan to engage with the UK's lawtech circle to ensure that the regulation does not place an unnecessary barrier in the way of innovation. This is a good sign. The conservative and traditional legal profession is now more receptive to legal technology.

\section{Legal Tech Service for Legal Firms in the UK}

In recent years, the legal service industry has witnessed rapid developments in technological advancement impacting legal firms. This can be seen through technological innovation in the tech market, ranging from advanced search and extraction; data analytics; document assembly and automation; and, conversation assembly, and automation. ${ }^{26}$

For instance, advanced search functions based on machine learning have the capability to identify specific legal information, blocks of text, clauses and anomalies. Machine learning is also able to pull valuable information from thousands of legal documents in record time. It extracts and summarises any provision from virtually any document or contract. This ensures speedy review of documents, to create a more efficient, cost-effective process of extracting information. In addition, the legal review can be completed 75 percent faster without the need for a paralegal, lawyers, or long

26 "Capturing Technological Innovation in Legal Services Report." The Law Society, accessed on November 2, 2019. https://www.lawsociety.org.uk/support-services/researchtrends/capturing-technological-innovation-report/. 
working hours. ${ }^{27}$ This technology takes out the tedious work and allows lawyers to focus on the decision that requires human logic.

Subsequently, data analytics emanating from increased computing power, data algorithm, and digital data, enables firms to gain insight into the workflow, cases, and clients. These data can be used to determine the value of the services they provide to clients. The data analytics helps identification of the 'right' cases for the firm, client needs, legal risk assessment, workflow, and case allocation.

Another category of technological innovation is document assembly and automation. The introduction of smart forms and robolawyers has transformed frequently used documents and forms into intelligent templates that enable fast production. Automating the assembly and production of documents saves time and money, reduces risk, increases accuracy, and enhances compliance. This system also enables non-lawyers to complete forms and produce a reliable draft of legal documents without expert legal knowledge.

The final category of technological innovation is conversation assembly and automation. It is operated by advanced natural language processing, voice recognition, machine learning, and document assembly tool. Natural language processing makes it possible for computers to read a text, hear speech, interpret, measure sentiment, and determine which parts are important. The use of chatbot and robo-lawyer combines with machine learning and natural language processing can provide users with information and generate a realtime document specific to a client's needs.

With the advent of technological innovation, the UK has seen an explosion in the number of legal tech start-ups in recent years. According to TechMarketView, an influential analyst and advisory company in the UK tech market, there are more than 100 legal tech companies operating in the UK. ${ }^{28}$ According to Lawyer Portal ${ }^{29}$ and

27 Thea Sokolowski, "4 AI Driven Lawtech Startups Changing the Legal Landscape," accessed on October 30, 2019, https://outsideinsight.com/insights/4-ai-driven-lawtech-startupschanging-the-legal-landscape/.

28 Michael Cross, "In Focus: Lawtech: Mind the Gap," Law Society Gazette, February 25, 2019, 10. 
Forbes, start-ups such as Luminance, ${ }^{30}$ Lexoo, ${ }^{31}$ Libryo $^{32}$ and Crowd Justice $^{33}$ emerged among the top legal start-ups in the UK for the year $2019 . .^{34}$

Luminance was formed in 2015 as a tech company that uses AI technology to read and understand contracts and legal documents with the aim of identifying significant information and anomalies. It does not require any instruction and is able to sift through documents in any language. By using $\mathrm{AI}$ rather than a trainee to go through piles of documents within a short span of time. Lawyers can now focus on works and areas of law that need a human touch, creative and analytical thinking. At present, Luminance has set sight on expansion into the US and Singapore.

Another start-up, Lexoo was founded in 2014. Lexoo established a platform through which clients can find lawyers by receiving multiple quotes from specialised solicitors. Clients can easily compare and hire talented and forward-thinking lawyers around the globe, all pre-screened and vetted by Lexoo. The lawyers are encouraged to compete for work and people can see hundreds of reviews from other businesses. A team of ex-lawyers performs the vetting so users will only receive quotes from lawyers that are right for the job. The lawyers are drawn from top firm lawyers who now work on a lower overhead basis. The Lexoo solution is easier, costeffective, and transparent.

29 “Top 5 Legal Tech Startups to Watch in 2019," The Lawyer Portal, accessed November 4, 2019, https://www.thelawyerportal.com/blog/top5-legal-tech-start-ups-to-watch-2019/.

30 See "Luminance. The Artificial Intelligence Platform for the Legal Profession," accessed on November 2, 2019, https://www.luminance.com/.

31 See "External Counsel for In-House Legal Teams," accessed on November 2, 2019, https://www.lexoo.co.uk/.

32 See "Libryo Provides World Class Legal Regulatory Technology for Organisations." accessed on November 2, 2019, https://libryo.com/.

33 See "The World's Crowdfunding Platform for Legal Action," accessed on November 2, 2019, https://www.crowdjustice.com/.

34 Alison Coleman, "Four Lawtech Startups Transforming the Way the Legal Sector Operates," Forbes, accessed November 4, 2019, https://www.forbes.com/sites/alisoncoleman/2019/08/18/four-lawtechstartups-transforming-the-way-the-legal-sector-operates/\#4a0ab91b545e. 
Libryo was established in 2016. It provides updates in the form of notifications on the latest changes to Regulatory Law. With built-in translations function, it enables clients to read legal texts in other languages. Libryo's context and place-specific collections of regulation provide on-demand, plain language summaries of specific sections of the applicable legislation. Libryo also tracks every applicable change in legislation and notifies the parties involved. Thus, it helps any person, working in any organization to know what the law requires in any situation.

CrowdJustice originally started in the UK in 2014. It is a crowdfunding platform where individuals, communities, or organizations can raise money specifically for legal cases. It aims to make the law accessible to all. CrowdJustice has a team of experts to vet each campaign to ensure a qualified lawyer has been engaged. They also ensure that all funds go to the lawyer's client trust account and disburse any leftover money should the case settle before the fund runs out.

\section{The UK Government Support for Legal Tech}

The rise in the number of lawtech companies shows that there is a demand for the adoption of legal tech in the legal profession. Numbers of legal tech companies have managed to pitch their businesses and received funding from investors and the UK government. In 2019, the sum of $£ 62$ million has been invested in UK legal tech start-ups. The government pledged another $£ 2$ million in June 2019 to support new and emerging technologies that will drive growth in the legal services industry ${ }^{35}$ and over forty grants were announced by the government to fund technological innovations. For instance, a grant of $£ 136,982.00$ has been awarded to Start-up Teal Legal Ltd and Keele University to develop a prototype tool on whether AI could speed up conveyancing by assisting the due diligence process. ${ }^{36}$ This commitment by the UK government will

35 "Legal Services and LawTech Bolstered with $£ 2$ million of Government Funding," UK Government, accessed November 5, 2019, https://www.gov.uk/government/news/legal-services-and-lawtechbolstered-with-2-million-of-government-funding.

36 Michael Cross, "News \& Technology: Online Legal Advice Boost in $£ 13 m$ support for AI,” Law Society Gazette, February 25, 2019, 8. 
help embrace opportunities of legal tech, drive innovations and help the UK legal industries to further prosper. For the record, legal services contribute around $£ 25$ billion to the UK economy and $£ 4$ billion in exports per year. ${ }^{37}$

\section{Legal Tech Regulation in the UK}

As discussed above, the UK legal profession has already embraced and become receptive to changes in the delivery of legal services. The change towards better legal service occurred long before the introduction of legal tech in the legal profession. This is witnessed by the introduction of the Legal Services Act 2007 (LSA). The LSA was introduced to regulate the legal practice and produce more competition within the sector. This is a response to the concerns raised about the outdated regulatory methods of the legal profession, the delivery of legal services as well as law firms overcharging due to the lack of competition. ${ }^{38}$ Therefore, the LSA, apart from its aim to liberalise and regulate the UK legal market, also aims to encourage more competition and to provide a new route for consumer complaints. The LSA has challenged the traditional legal profession as it paves the way to allow competition in the legal profession. Currently, the LSA enables external ownership of law firms by nonlawyers, lawyers, and accountants to become partners under alternative business structures (ABSs), and for law firms to get listed on the stock market. The introduction of the ABS signifies the liberalisation of the UK legal profession and this provides excellent opportunities for future legal tech development in the UK.

37 "Legal Services and LawTech Bolstered with $£ 2$ million of Government Funding," UK Government, accessed November 5, 2019, https://www.gov.uk/government/news/legal-services-and-lawtechbolstered-with-2-million-of-government-funding.

38 In 2004, Sir David Clementi published his report i.e. Clementi Review after a study conducted in 2003 to consider a framework that would best promote competition, innovation, and the public and consumer interest in an efficient, effective and independent legal sector. His recommendations were reflected in the LSA 2007. See Michael Zander, "The Legal Services Act 2007: An Act of Revolution for the Legal Profession?” Legal Services Institute, accessed on November 15, 2019, https://sdn.ymaws.com/ncbp.org/resource/collection/F9556696-FF20442A-B922-OFE6CFD2FB3E/The_Legal_Services_Act_2007.pdf. 


\section{LEGAL TECH IN MALAYSIA: RECENT DEVELOPMENT}

\section{AND THE WAY FORWARD}

In his speech to commemorate the Legal Year 2019, former Chief Justice of Malaysia - YAA Richard Malanjum (as he then was) explained how technology assists in the court administration. The introduction of an E-review in case management, queue management system (QMS), complaint mechanism, and video conferencing and so on, virtual court and paperless system indicated that Malaysia is changing its traditional legal system into a digital legal system. By introducing a digital system, the court is minimizing the burden faced by lawyers in handling their case and assisting the public to improve access to justice and fair decisions from the court. As the courts are going digital, the Chief Justice reminded the legal profession to embrace technology because there is no option since technology is coming soon to the legal profession.

Taking heed of the Chief Justice's advice, the Bar Council has submitted to the Attorney General's office a draft of the new Legal Profession Act in January 2019. According to Foong Cheng Leong, a member of the Committee on the Reform of Legal Sector, the new Act seeks "to account for developing trends and technological innovation in the legal profession". Section 35 of the new Act contains a provision on Legal Technology. ${ }^{39}$

The section consists of seven provisions comprising the definition of legal technology and legal technology providers. The provision defines legal technology as "any technological product or service used or to be used in the provision of any service or any act which is within any function or responsibility of any advocate and solicitor, or places at the disposal of any other person the services of an advocate and solicitor".

The provision covers two parts namely:

39 Foong Cheng Leong, "Introduction of Legal Technology Provision in the New Malaysian Legal Profession Act," accessed on 30 October 2019, https://foongchengleong.com/2019/01/introduction-of-legaltechnology-provision-in-the-new-malaysian-legal-profession-act/. 
a. Technological product or service provided by lawyers or advocates and solicitors;

b. Technological product or service provided by non-lawyers who provide service as advocates and solicitors.

Whereas 'legal technology provider' refers to any person or entity that provides legal technology.

In summary, the new LPA recognises the use of legal technology services and product by lawyers in the delivery of legal services. Lawyers as members of the Bar can resort to legal tech to improve quality of work, increase performance, and enhance professionalism. However, using technology to solicit clients or touting is still prohibited under the Legal Profession (Practice \& Etiquette) Rules 1978.

In relation to the power of the Bar Council, Section 35 (2) confers the Bar Council with the power to make rules for the regulation of any legal technology or legal provider. Subsection (3) mandated the Bar Council with the power to exempt any legal technology or legal technology provider from any rules of the Bar Council and from the requirement under Section 33 that governs the issuance of Sijil Annual. The Bar Council may revoke any approval or exemption given if the legal technology provider contravenes this section. To determine any contravention of the section, the Bar Council has the power to conduct an inquiry and compel any person to produce any document. In cases where the contravention is proven, Section 35(7) gives the power to the Bar Council to apply to the High Court for the following order:

a. to restrain the legal technology provider from providing its product, service or solution;

b. to compel the relevant authority to disclose any further relevant information related to the contravention;

c. to compel the relevant authority to restrain or limit access to such legal technological providers. 
The new provision is an opportunity, although limited, for legal tech to work together with lawyers to provide legal service. The existence of legal tech still depends on the approval and discretion of the Bar. Looking at the new Act, the Bar Council still retains wide powers to regulate the development of the legal tech in Malaysia.

Indirectly, this development is clouded by the decision of the court in the case of Index Continent ${ }^{40}$ and the power of the Bar Council. Since 2017, there have been eight legal tech start-ups operating in Malaysia namely LawCanvas, CanLaw, CanLawSyariah, BurgeLaw, Locum Legalis, FCL \& Co., Easylaw, and eLaw. However, CanLaw has permanently closed while others are not active or have to change their business structure and concept. Only FCL \& Co., which is operated by a lawyer, survived. The development of legal tech was slow at first. Nevertheless in 2019, a transformation started to emerge with the incorporation of LawTech Malaysia, which aims to promote effective and long-term digital transformation in the legal industry in Malaysia and the ASEAN region.

In October 2019, the Company organised a hackathon to solve four problems relating to legal service and management, namely, "reducing the overhead cost for law firms, increasing access to justice, improving communication among industry stakeholders and cultivating innovative culture". According to Adeline Chin, the Malaysian Hackathon identifies four issues faced by law firms which are "challenge of dealing with paper-heavy, need more efficient processes and practice management and in relation to access to justice, the public needs a legal market place". ${ }^{41}$ The Hackathon acted as an eye-opener to lawyers who joined the event.

On the issue of whether artificial intelligence (AI) will replace lawyers and take away their jobs, the answer obtained was "the AI is only doing mechanical tasks but a lawyer's oversight and authority to sign a matter is still a necessity". This ruled out the fear of losing a job among lawyers because what AI offers is 'efficiency, fast and accurate'. In other words, AI would offer a massive boost to productivity, allowing for smarter searches through massive

40 Bar Malaysia v Index Continent Sdn Bhd [2016] 2 CLJ 545 (FC).

41 Qishin Tariq, "Changing Perceptions: Reaching Lawyers through Legal Tech Education," Technews The Star Online, Feb 2019. 
documentations and able to contextualise and understand terms used by lawyers.

\section{CONCLUSION}

Unlike the US and the UK where the ABA and the Law Society took active parts in promoting legal tech, the Bar Council still maintains its position as a regulatory body. Nevertheless, the Hackathon is seen as creating better ties with the Bar Council and opportunities to link with the State Bars namely Perak Bar, Penang Bar, Sabah Law Society, and Asian International Arbitration Centre. Such an event shows the positive reception of lawyers especially lawyers who are able to use the legal tech to improve their lawyering skills and work. In addition, such an event provides an avenue for young and creative law students to produce legal tech products such as chatbot to ease the process of drafting agreements especially in the area of conveyancing by digitising the procedures. Even though the documentation can be automated, a lawyer's signature and verification are still very much needed.

Finally, legal tech facilitates better, faster, efficient and reliable legal services. It also helps the public to have access to justice and assist lawyers in providing a better service to the public, especially in this digital era. In this regard, the legal tech should be seen as opportunities for the legal profession to improve the delivery of the legal service and be allowed to shape the future legal profession in Malaysia. Tightening legal services regulation may hinder access to justice and the development of legal tech. However, no regulation may threaten and jeopardise the legal service and business of members of the legal profession. The Bar Council must, therefore, exercise its discretion vigilantly in protecting the traditional landscape of the legal profession and in supporting the digital inclusion that brings access to justice nearer to the public. 